\title{
尿路結石の成因に関する研究
}

\section{一各種条件下の尿中 $\gamma$-カルボキシグルタミン酸排泄量について一}

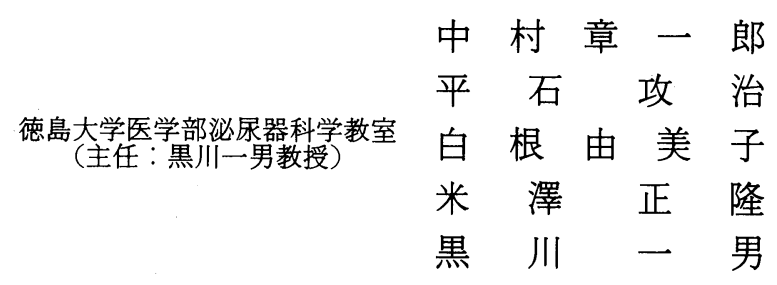

\author{
STUDY ON THE CAUSATIVE FACTOR PRODUCING URINARY CALCIUM STONES \\ -Excretion on Urinary $\gamma$-Carboxyglutamic Acid in Various Conditions- \\ Shoichiro Nakamura, Koji Hiraishi, Yumiko Shirane, Masataka Yonezawa \\ and Kazuo Kurokawa
}

Department of Urology, Faculty of Medicine, University of Tokushima, Tokushima, Japan

(Director: Prof. K. Kurokawa)

We have previously reported that the excretion of urinary $\gamma$-carboxyglutamic acid (Gla) in calcium stone formers was lower than that in healthy adults. However, it has not yet been clarified whether this is caused by inhibitory actions of Gla on calcium stone formation or Gla is only adsorbed on the surface of stones.

In order to clarify this point, we compared the urinary Gla-excretion in the presence and absence of calcium stones. Moreover, also investigated the urinary Gla-excretion before and after ingestion of low calcium diet or administering thiazide in patients with idiopathic hypercalciuria to observe how Glaexcretion varies with changes of the urinary Gla-excretion.

In the presence of stones, urinary Gla-excretion was $38.3 \pm 8.6 \mu \mathrm{mol} / \mathrm{day}$ in males (12 patients) and $30.7 \pm 5.3 \mu \mathrm{mol} /$ day in females ( 7 patients). After extripation of the stones, it increased to $42.2 \pm$ $5.7 \mu \mathrm{mol} /$ day in males and to $39.5 \pm 7.0 \mu \mathrm{mol} /$ day with a significant difference $(\mathrm{p}<0.001)$ in females.

In the case of ingestion of low calcium diet, the values before and after ingestion were $39.5 \pm$ $8.6 \mu \mathrm{mol} /$ day and $41.6 \pm 7.3 \mu \mathrm{mol} /$ day, respectively, in males (17 patients), and $34.5 \pm 7.8 \mu \mathrm{mol} / \mathrm{day}$ and $37.0 \pm 4.4 \mu \mathrm{mol} /$ day, respectively, in females (6 patients), without significant difference.

In the case of administration of thiazide, the values before and after administration were $40.9 \pm$ $7.1 \mu \mathrm{mol} /$ day and $45.2 \pm 7.5 \mu \mathrm{mol} /$ day in males (11 patiens), and $38.2 \pm 7.2 \mu \mathrm{mol} / \mathrm{day}$ and $36.7 \pm$ $6.5 \mu \mathrm{mol} /$ day in females (10 patients), respectively, without significant difference.

From the above results, we inferred that decrease in the urinary Gla-excretion was caused by the action that urinary Gla is adsorbed on the surface of stones independent of changes of the urinary calcium-excretion.

\footnotetext{
要旨：われわれは，カルシウム（以下 $\mathrm{Ca}$ ) 結石症患者の尿中 $\gamma$-カルボキシグルタミン酸 (以下 Gla) 排 泄量が健常者に比し低値を示すことはすでに報告した. この理由として, Gla が Ca 結石形成の抑制因子 として働いているのかもしれないが，ただ単に結石表面に吸着されているだけかもしれない。このこと を明らかにするために, Ca 結石存在下と非存在下に拈ける尿中 Gla 排泄量を比較検討した。 また, 尿中 $\mathrm{Ca}$ 排泄量の変化に対し, Gla 排泄量はいかに変動するのかをみるために, 特発性高 $\mathrm{Ca}$ 尿症患者に扔い て，低 $\mathrm{Ca}$ 食前後，およびサイアザイド剂投与前後の尿中 Gla 排泄量を比較検討した。

結石存在下では, 男性 $(\mathrm{n}=12)$ では, $38.3 \pm 8.6 \mu \mathrm{mol} / \mathrm{day}$ で, 女性 $(\mathrm{n}=7)$ では, $30.7 \pm 5.3 \mu \mathrm{mol} /$
} 
day であり, 結石摘出後は, 男性で $42.2 \pm 5.7 \mu \mathrm{mol} / \mathrm{day}$ と増加傾向にあり,女性では $39.5 \pm 7.0 \mu \mathrm{mol} / \mathrm{day}$ と有意に増加した（ $\mathrm{p}<0.01 ）$.

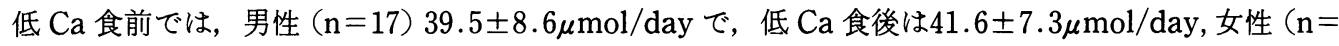
6）では， $34.5 \pm 7.8 \mu \mathrm{mol} / \mathrm{day}$ から $37.0 \pm 4.4 \mu \mathrm{mol} / \mathrm{day}$ といずれも有意差は認められなかった.

サイアザイド剂投与前では，男性（ $\mathrm{n}=11 ） 40.9 \pm 7.1 \mu \mathrm{mol} / \mathrm{day}$ で，投与後は $45.2 \pm 7.5 \mu \mathrm{mol} / \mathrm{day}$, 女性 $(\mathrm{n}=10)$ では, $38.2 \pm 7.2 \mu \mathrm{mol} / \mathrm{day}$ から $36.7 \pm 6.5 \mu \mathrm{mol} / \mathrm{day}$ といずれも有意差は認められなかっ た.

以上の結果より，尿中 Gla 排泄量は尿中 $\mathrm{Ca}$ 排泄量の変動による影響は受けず，尿中 Gla が結石に吸 着されている可能性があると考兄られた。

\section{緒言}

$\gamma$-カルボキシグルタミン酸(以下 Gla)は, カルシウ ム（以下 $\mathrm{Ca}$ ) との結合力が強い性質を有し，Gla 含有 蛋白質は, calcium-binding protein として各分野で注 目されている. 1977年, Lian ら る尿路結石中に Gla を多く含んだ蛋白質を認めたと 報告した。われわれは, Gla が Ca 含有結石形成に何ら かの役割を果していると考克，尿中 Gla 排泄量を測定 し報告した。ただし，尿中の Gla は大部分が遊離形で あり, 結石中に認められた Gla 含有蛋白質ではない。

われわれの成績では，尿中 Gla 排泄量は男性の方が 女性より高值を示し, $\mathrm{Ca}$ 結石症患者は健常者に比し低 值を示した ${ }^{2)}$.この理由として, Gla が $\mathrm{Ca}^{++}$とキレート 結合することょり, Ca 結石形成の抑制因子としての役 割も考えられるが，ただ単に結石表面に吸着されてい るだけかもしれない.このことを明らかにするために, $\mathrm{Ca}$ 結石存在下と非存在下に打ける尿中 Gla 排泄量を 比較検討した。また, 尿中 Ca 排泄量の变化に対し, Gla 排泄量はいかに変動するのかをみるために, 特発性高 $\mathrm{Ca}$ 尿症患者に括いて，低 $\mathrm{Ca}$ 食前後，およびサイアザ イド剂投与前後の尿中 Gla 排泄量を比較検討した。

\section{対象と方法}

1. 結石摘出前後の尿中 Gla 排泄量

対象は, 短径 $2 \mathrm{~cm}$ 以上の上部尿路結石を有し，その 結石成分に Ca が含まれ，対側腎に結石のない症例で, 高度の尿路感染症を有する例と手術の際腎実質に切開 を加えた例は除いた。男性は12例で平均年龄は51.8歳 (32 70歳), 女性は 7 例で平均年齢は 44.6 歳（30 62 歳）であった。

これらの症例に, 手術前後に病院普通食下 $(\mathrm{Ca}$ $600 \sim 700 \mathrm{mg} /$ day, P $1,200 \sim 1,400 \mathrm{mg} /$ day 含有) で, 各々 24 時間尿を連続 3 日間採取し, 尿中 Gla 排泄量を 測定し平均值をとった。なお, 手術後の測定は, 輸液, 薬剂を中止した時点（手術後約 2 週目）で行なった。
2. 低 $\mathrm{Ca}$ 食前後の尿中 $\mathrm{Gla}$ 排泄量

対象は，上部尿路に $\mathrm{Ca}$ 含有結石を有する特発性高 $\mathrm{Ca}$ 尿症患者（表 1) で，男性は17例で平均年齢は 49.8 歳 (26 80歳), 女性は 6 例で平均年齢は 46.7 歳 ( $30 \sim 62$ 歳)であった。

これらの症例に, 病院普通食下で連続 3 日間 24 時間 尿を採取し, 次いで低 $\mathrm{Ca}$ 食 (Ca $130 \mathrm{mg} / \mathrm{day})$ を 5 日 間投与し, 最後の 3 日間の 24 時間尿を採取した。尿中 Gla 排泄量は各々の平均值で検討した。

3. サイアザイド剤投与前後の尿中 Gla 排泄量

対象は，上部尿路に $\mathrm{Ca}$ 含有結石を有する特発性高 $\mathrm{Ca}$ 尿症患者で, 男性は11例で平均年齢は48.5歳 (26 60歳), 女性は10例で平均年齢は53.2歳（34 70 歳)であった。

これらの症例に, 病院普通食下で連続 3 日間24時間 尿を採取し，次いでサイアザイド剤（trichlormethiazide） $4 \mathrm{mg} / \mathrm{day}$ を 1 週間投与し, 最後の 3 日間の 24 時間尿を採取した。尿中 Gla 排泄量は各々の平均値で 検討した.

各症例とも血清クレアチニン值に異常がなく，骨疾 患を有していない例を選んだ。なお，蓄尿に際しては 防腐剤の添加は行なわなかった。

尿中 Gla 測定法は Per Fernlund ${ }^{3)}$ の方法に従った

\section{表 1 特発性高 $\mathrm{Ca}$ 尿症}

1)尿路 $\mathrm{Ca}$ 結石

2) 血清 $\mathrm{Ca}$ 值が正常

3）尿中 $\mathrm{Ca}$ 排泄量

男性：250 mg/day 以上 女性 : $200 \mathrm{mg} / \mathrm{day}$ 以上

（普通食下：600 700 mg Ca/day， $1200 \sim 1400 \mathrm{mg} \mathrm{P} / \mathrm{day})$

4）尿路結石の他の原因が㸾められない 
が，その詳細については白根ら出がすでに報告してい るので省略する。な挔，尿中 $\mathrm{Ca}$ 排泄量は，オートアナ ライザーによる Orthocresophthalein Complexone 法 にて測定した。

\section{結 果}

1. 結石摘出前後の尿中 Gla 排泄量

結石存在下での尿中 Gla 排泄量は, 男性では38.3土 $8.6 \mu \mathrm{mol} /$ day で結石摘出後は $42.2 \pm 5.7 \mu \mathrm{mol} / \mathrm{day}$ と 増加傾向にあった. 女性では $30.7 \pm 5.3 \mu \mathrm{mol} / \mathrm{day}$ から $39.5 \pm 7.0 \mu \mathrm{mol} / \mathrm{day}$ と有意に増加 $(\mathrm{p}<0.01)$ した（図 1).

尿中 Gla 濃度について同様の検討をすると，男性で は26.3 $\pm 9.7 \mu \mathrm{mol} / l$ から $23.0 \pm 9.0 \mu \mathrm{mol} / l$ で, 女性で は21.6 $\pm 3.2 \mu \mathrm{mol} / l$ から $30.8 \pm 10.5 \mu \mathrm{mol} / l$ といずれ も有意差は認められなかった（図 2 ）。

2. 低 $\mathrm{Ca}$ 食前後の尿中 $\mathrm{Gla}$ 排泄量

低 $\mathrm{Ca}$ 食前の尿中 $\mathrm{Ca}$ 排泄量は男性では $282 \pm 35.1$ $\mathrm{mg} / \mathrm{day}$ で，低 $\mathrm{Ca}$ 食後は $156 \pm 53.9 \mathrm{mg} /$ day と有意に 低下（p<0.01）し，女性でも $240 \pm 36.3 \mathrm{mg} /$ day から

図 1 結石摘出前後の尿中 Gla 排泄量の変動

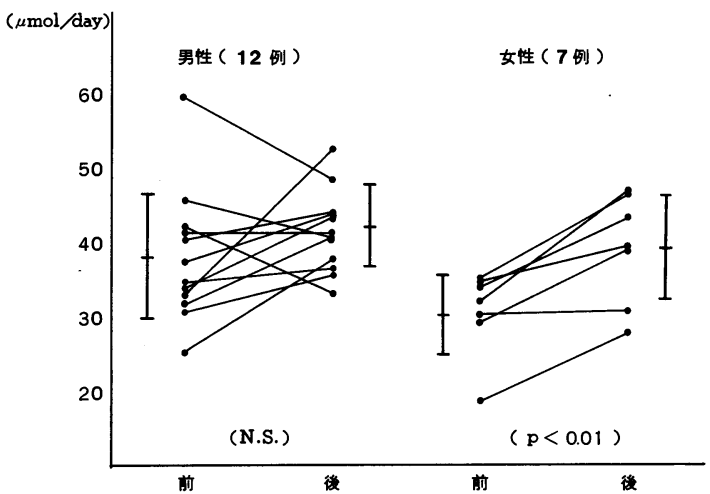

図 2 結石摘出前後の尿中 Gla 濃度の変動

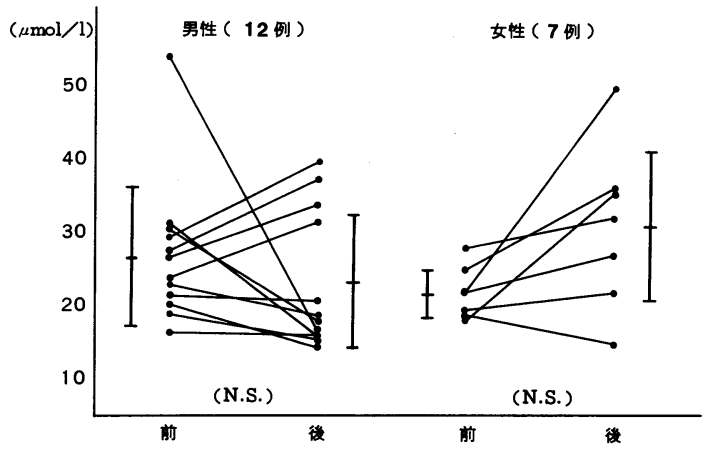

$145 \pm 41.8 \mathrm{mg} / \mathrm{day}$ と有意に低下（p<0.01）した（図 3 ).

尿中 Gla 排泄量は男性では $39.5 \pm 8.6 \mu \mathrm{mol} / \mathrm{day}$ か $ら 41.6 \pm 7.3 \mu \mathrm{mol} / \mathrm{day}$ で，女性では $34.5 \pm 7.8 \mu \mathrm{mol} /$ day から $37.0 \pm 4.4 \mu \mathrm{mol} / \mathrm{day}$ といずれも有意差は認 められなかった（図 4)。

濃度では, 男性は $25.7 \pm 11.0 \mu \mathrm{mol} / l$ から $25.0 \pm 8.4$ $\mu \mathrm{mol} / l$, 女性は $19.8 \pm 4.2 \mu \mathrm{mol} / l$ から $17.5 \pm 3.2$ $\mu \mathrm{mol} / l$ といずれも有意差は認められなかった（図

図 3 低 $\mathrm{Ca}$ 食前後の尿中 $\mathrm{Ca}$ 排泄量の変動

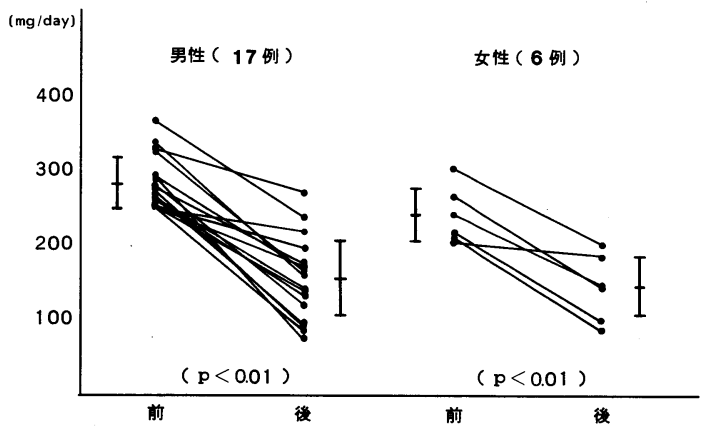

図 4 低 $\mathrm{Ca}$ 食前後の尿中 $\mathrm{Gla}$ 排泄量の変動

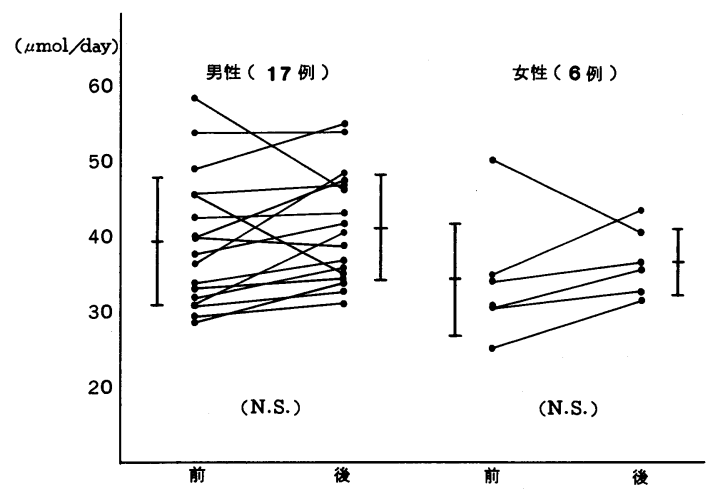

図 5 低 $\mathrm{Ca}$ 食前後の尿中 $\mathrm{Gla}$ 濃度の変動

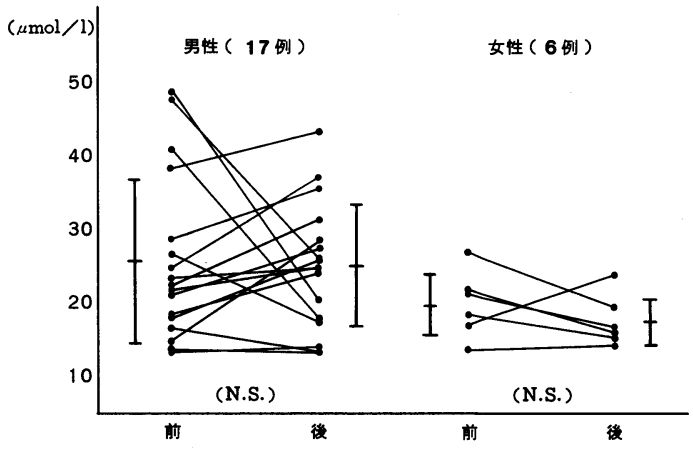


5 ).

3. サイアザイド剤投与前後の尿中 Gla 排泄量

サイアザイド剤投与前の尿中 $\mathrm{Ca}$ 排泄量は, 男性で は281 $\pm 36.2 \mathrm{mg} /$ day で, 投与後は $161 \pm 57.3 \mathrm{mg} /$ day と有意に低下 $(\mathrm{p}<0.01)$ 乙，女性でも $274 \pm 64.2 \mathrm{mg} /$ day から $156 \pm 50.7 \mathrm{mg} /$ day と有意に低下 $(\mathrm{p}<0.01)$ 乙 た（図6).

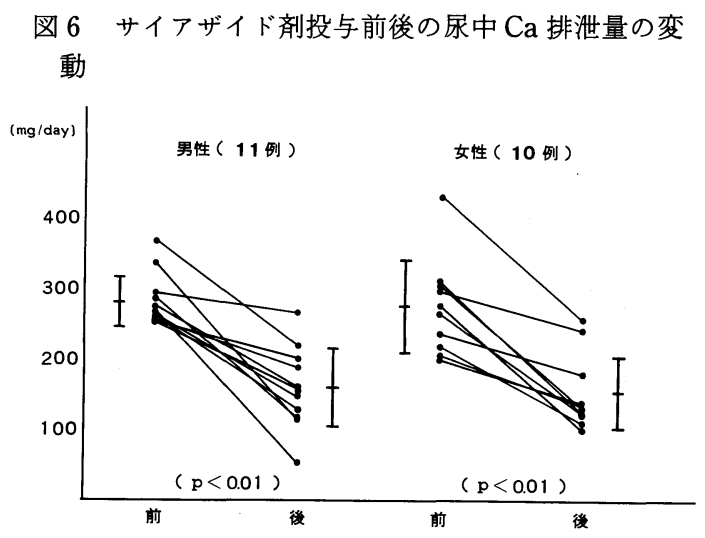

図 7 サイアザイド剤投与前後の尿中 Gla 排泄量の 変動

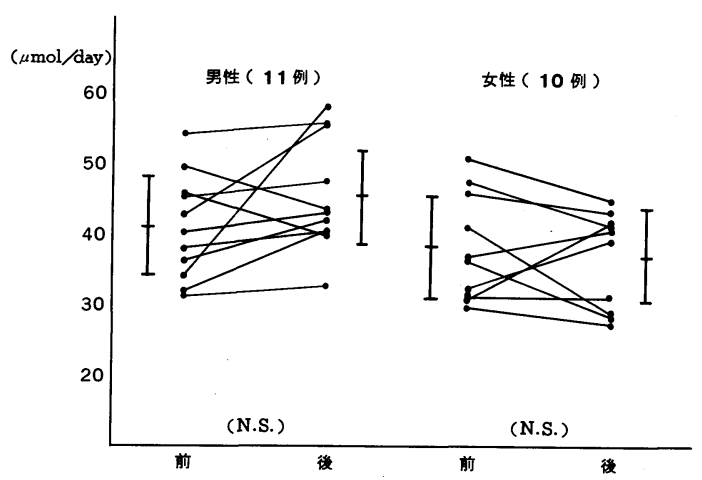

図 8 サイアザイド剂投与前後の尿中 $\mathrm{Gla}$ 濃度の変 動

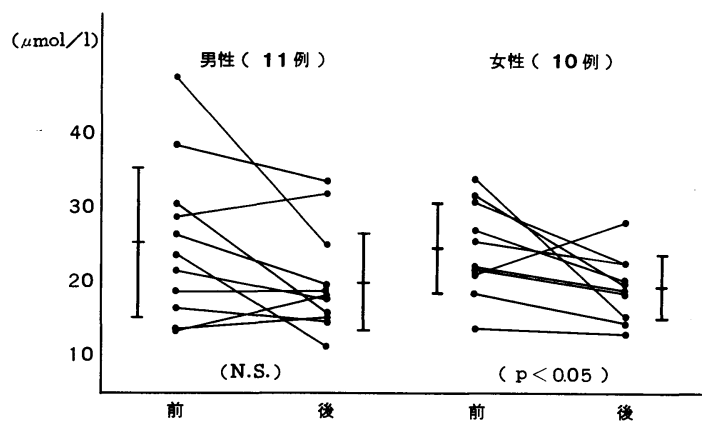

尿中 Gla 排泄量は男性では40.9 $\pm 7.1 \mu \mathrm{mol} / \mathrm{day}$ か ら $45.2 \pm 7.5 \mu \mathrm{mol} / \mathrm{day}$ で, 女性では $38.2 \pm 7.2 \mu \mathrm{mol} /$ day から $36.7 \pm 6.5 \mu \mathrm{mol} / \mathrm{day}$ といずれも有意差は認 められなかった（図 7 ).

濃度では，男性は $25.2 \pm 10.0 \mu \mathrm{mol} / l$ から $20.0 \pm 6.8$ $\mu \mathrm{mol} / l$ と有意差はなく, 女性は $24.3 \pm 6.0 \mu \mathrm{mol} / l$ 力 ら $19.1 \pm 4.2 \mu \mathrm{mol} / l$ と有意に低下 $(\mathrm{p}<0.05)$ した（図 8 ).

\section{考案}

$\gamma$-カルボキシグルタミン酸は, 1974年に, Stenflo ら5)によって，プロトロンビンを構成するアミノ酸の $1 つ と し て$ 発見され，以後，血液中以外にも，骨の Gla 含有蛋白質 (オステオカルシン)6)，アテローム性動脈 硬化部位の Gla 含有蛋白質 (アテロカルシン) 7), その 他, 腎8)，異所性石灰化部 ${ }^{9)}$ な゙で Gla 含有蛋白質がみ つかっている。ささらに, 1977年, Lian ら ${ }^{11}$ は, Caを含 んだ腎結石中に Gla 含有蛋白質の存在を明らかにし た。そして，尿路結石中でも，Caを含まない尿酸，シ スチン，純粋なリン酸マグネシウム，アンモニウム結 石には認められなかったとしている。

$\mathrm{Gla}$ の $\mathrm{Ca}^{++}$との親和性や, 尿路結石でも, $\mathrm{Ca}$ を含ま ない結石中には存在しないことからも, Ca 結石形成に Gla が関与していることが予想される.

尿中 Gla 排泄量は, Ca 結石症患者では, 男性 (41例) $38.3 \pm 7.8 \mu \mathrm{mol} / \mathrm{day}$, 女性 (30例) $34.2 \pm 8.6 \mu \mathrm{mol} /$ day で, 健常人では, 男性 (24例) $48.6 \pm 8.8 \mu \mathrm{mol} / \mathrm{day}$, 女 性 (11例) $36.6 \pm 6.4 \mu \mathrm{mol} / \mathrm{day}$ であり, Ca 結石症患者 では健常人に比し，Gla 排泄量が低值を示したことは すでに報告した2).

今回, 結石存在下と非存在下での尿中 Gla 排泄量, 低 $\mathrm{Ca}$ 食前後及びサイアザイド剂投与前後の尿中 Gla 排泄量の比較検討を行なった。

結石存在下では，尿中 Gla 排泄量が減少する傾向が あり, 結石に Gla が吸着されている可能性を示す結果 であった。しかし，これが単なる吸着か，マトリック スとして働いているのかは不明で, 今後の課題である.

低 $\mathrm{Ca}$ 食及びサイアザイド剤投与により，尿中 $\mathrm{Ca}$ 排 泄量は著明に減少するが，尿中 Gla 排泄量には変化な く，尿中 Ca 排泄量の変動による影響は受けないこと も判明した。

尿中 Gla はほとんどが遊離形で，ごくわずかのもの が蛋白質と結合しているといわれている10). また，骨疾 患の程度によっても増減し11), ワーファリン投与に よって減少する ${ }^{12)}$. ワーファリン長期投与患者に尿路 
結石が生ずるといら事実はなく, 尿中 Gla 排泄量と尿 路結石形成とは直接関係しないかもしれない。むしろ, 遊離形の Gla と Gla 含有蛋白質とを別個に考光る必 要があると思われる。

種々の部位で発見されている Gla 含有蛋白質は, ア ミノ酸構成が少しずつ異なっており，Ca 結石中の $\mathrm{Gla}$ 含有蛋白質が，腎に存在する Gla 含有蛋白質と同一の ものであるか否かを明らかにすること，が大切だと思 われる。

腎の Gla 含有蛋白質は皮質に存在するといわれて いるが，腎皮質のどの部位に局在しているのか，また， その部位でどのような生理的役割を演じているのか, さらに, Ca 結石形成時には, どのような变化が生じて

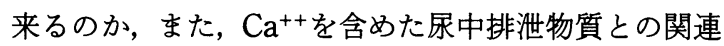
はどらなっているのか，まだをだ不明な点が多い。わ れわれも現段階では，遊離形の Gla しか測定していな いが，今後は Gla 含有蛋白質に焦点をあわせて検討し ていく予定である.

\section{結 語}

1. 上部尿路 $\mathrm{Ca}$ 結石の存在下と非存在下の尿中 Gla 排泄量を測定した結果, 結石存在下では尿中 Gla 排泄量は減少する傾向があり，結石に Gla が吸着され ている可能性がある。

2. 低 $\mathrm{Ca}$ 食及びサイアザイド剤投与により尿中 $\mathrm{Ca}$ 排泄量は有意に減少するが, 尿中 Gla 排泄量には変化 はなかった。

本論文の要旨は日本泌尿器科学会第 36 回西日本総会に打 いて発表した。

\section{文献}

1) Lian, J.B., Prien, E.L., Glimcher, M.J. and Gallop, P.M.: The presence of protein-bound $\gamma$. carboxyglutamic acid in calcium-containing renal calculi. J. Clin. Invest., 59, 1151-1157, 1977.

2）中村章一郎, 白根由美子, 平石攻治, 黒川一男: 尿 路結石の成因に関する研究一結石患者に拈ける尿 中 $\gamma$-カルボキシグルタミン酸の排泄量について。 日泌尿会誌, 75, 744-750, 1984.

3) Fernlund, P.: $\gamma$-Carboxyglutamic acid in human urine. Clin. Chim. Acta, 72, 147-155, 1976.
4）白根由美子, 中村章一郎, 平石攻治, 黒川一男：高 速アミノ酸分析法に上る尿中 $\gamma$-Carboxyg. lutamic acid の測定. 臨床化学, 12, 297-303, 1983.

5) Stenflo, J., Fernlund, P., Egan, W. and Roepstorff, P.: Vitamin K-dependtent modifications of glutamic acid redidues in prothrombin. Proc. Natl. Acad. Sci. U.S.A., 71, 2730-2733, 1974.

6) Hauschka, P.V. and Gallop, P.M. : Purification and calcium-binding properties of osteocalcin, the $\gamma$-carboxyglutamate-containing protein of bone. Calcium binding proteins and calcium function, ed. by R.H. Wasserman, R.A., Corradino, E. Carafoli, R.H. Kretsinger, D. H. MacLennan and F.L. Siegel, Elservier-North Holland, New York, 338-347, 1977.

7) Levy, R.J., Lian, J.B. and Gallop, P.M. : Atherocalcin, a $\gamma$-carboxyglutamic acid containing protein from atherosclerotic plaque. Biochem. Biophys. Res. Commun., 91, 41-49, 1979.

8) Huschka, P.V., Friedman, P.A., Traverso, H.P. and Gallop, P.M.: Vitamin K-dependent $\gamma$ acrboxyglutamic acid formation by kidney microsomes in vitro. Biochem. Biophys. Res. Commun., 71, 1207-1213, 1976.

9) Lian, J.B., Skinner, M., Glimcher, M.J. and Gallop, P.M.: The presence of $\gamma$-carboxyglutamic acid in the proteins associated with ectopic calcification. Biochem. Biophys. Res. Commun., 73, 349-355, 1976.

10) Kian, J.B., Glimcher, M.M.J. and Gallop, P.M. : Identification of $\gamma$-carboxyglutamic acid in urinary proteins. Calciuim binding proteins and calcium function, ed. by R.H. Wasserman, R.A. Corradino, E. Carafoli, R.H. Kretsinger, D.H. MacLennan and F.L. Siegel, Elsevier-North Holland, New York, 379-381, 1977.

11) Gallop, P.M., Lian, J.B. and hauschka, P.V.: Carboxylated calcium-binding proteins and vitamin K. N. Engl. J. Med., 302, 1460-1466, 1980.

12) Levy, R.J. and Lian, J.B.: $\gamma$-carboxyglutamate excretion and warfarin therapy. Clin. Pharmacol. Ther., 25, 562-570, 1979.

(1985年 3 月 6 日受付) 